\title{
急冷処理による酸素過剩添加チタン材の延性向上と その機構解明
}

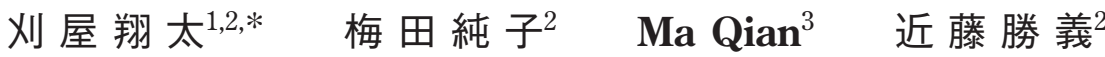

\author{
${ }^{1}$ 大阪大学大学院工学研究科機械工学専攻 \\ 2 大阪大学接合科学研究所
}

${ }^{3}$ Centre for Additive Manufacturing, School of Engineering, RMIT University

J. Japan Inst. Met. Mater. Vol. 82, No. 10 (2018), pp. 390-395

(C) 2018 The Japan Institute of Metals and Materials

\section{Ductility Improvement Mechanism of Pure Titanium with Excessive Oxygen Solid Solution via Rapid Cooling Process}

\author{
Shota Kariya ${ }^{1,2, *}$, Junko Umeda ${ }^{2}$, Qian $\mathrm{Ma}^{3}$ and Katsuyoshi Kondoh ${ }^{2}$ \\ ${ }^{1}$ Graduate School of Engineering, Osaka University, Suita 565-0871 \\ ${ }_{2}^{2} J o i n i n g$ and Welding Research Institute, Osaka University, Ibaraki 567-0047 \\ ${ }^{3}$ Centre for Additive Manufacturing, School of Engineering, RMIT University, Melbourne
}

Oxygen solid solution has been well known to have a high hardening effect on Ti and its alloys, while it also imposes a serious embrittlement behavior. This study investigated the effect of a rapid cooling process by water quenching (WQ) after heat treatment on the microstructures and mechanical properties of powder metallurgy (PM) $\alpha$-titanium (Ti) materials with dissolved 0.94 mass $\%$ oxygen $(\mathrm{O})$ to clarify their ductility improvement mechanism. The water quenching was applied to PM Ti extruded rod after isothermal annealing at $1173 \sim 1373 \mathrm{~K}$. Tensile test results at the ambient temperature indicated that the elongation to failure of the quenched ones at $1223 \mathrm{~K}$ and $1273 \mathrm{~K}$ was $12.5 \%$ and $19.1 \%$, respectively. They are significantly higher than that of as-extruded Ti specimen $(6.0 \%)$. The Ti- 0.94 mass \% O materials via the above WQ treatment mainly consisted of equiaxed $\alpha$-Ti grains, and some martensite phases were also detected at the grain boundaries. They were formed from $\beta$ phases during phase transformation during WQ due to a lower oxygen content in pre- $\beta$ phases compared to pre- $\alpha$ phases. The pre- $\beta$ phase also had a high concentration of dislocation after tensile test. The significantly increased elongation was due to a lower oxygen content phase formation assuming an important role to improve the plastic deformation ability. [doi:10.2320/jinstmet.JAW201810]

(Received May 15, 2018; Accepted June 18, 2018; Published August 24, 2018)

Keywords: titanium, oxygen, solid solution, ductility improvement, rapid cooling

\section{1. 緒言}

チタン $(\mathrm{Ti})$ は，高比強度と緻密酸化皮膜に起因する高耐腐 食性能, オッセオインテグレーション(チタンと骨の結合)に 起因する高い生体親和性といった優れた特性を有しており ${ }^{1,2)}$, アルミニウムやマグネシウムなどの軽金属, ステンレス鋼の ような高耐食性金属では適用に課題があった医療デバイス ${ }^{3-6)}$ や輸送機器7) を始めとした幅広い産業分野にて利用が進んで いる。これらの部材へのチタンの適用に際しては，機械特性 の観点から純チタンではなくチタン合金が使用されることが 多い.しかしながら，現行のチタン合金においては，沉用 Ti-6Al-4V 合金(JIS60種, ASTM B348 Gr5，64チタン合金)に 代表される $\alpha+\beta$ 型合金が主流となっているが, $\beta$ 相の安定化 には, VやCr, Mo といったレアメタルの添加が必須となる ${ }^{8)}$. また，これらの一部は毒性を有しているため，合金元素の種 類やその添加量によっては, 純チタン材に対して延性や生体

\footnotetext{
* 大阪大学大学院生 (Graduate Student, Osaka University)
}

親和性の低下，また素材価格の上昇や供給不安などの課題を 伴う.

これらの理由から，資源的に普遍に存在し，安定供給が可 能で安価なユビキタス元素を活用した新たなチタン合金の材 料設計指針が，近年，注目を集めている，その例として，炭 素とチタンの反応による炭化チタンのチタン素地中への分散 強化 ${ }^{9,10)}$, シリコン添加による結晶粒微細化強化 ${ }^{11,12)}$, チ夕ン 母相への酸素や窒素の侵入固溶強化 ${ }^{13-21)}$ などが挙げられる. なかでも, 酸素による侵入固溶強化は優れた強化能を有して いる. しかしながら，一般に，チタンへの酸素の添加は延性 の著しい低下を招くとされており，チタン材においては，JIS1 種チタンでは 0.15 mass \%, JIS4種チタンでは 0.40 mass \% と 厳しく制限されている。ここで，Jaffee らにより報告された， 0.00 ～ 0.80 mass\%の酸素を添加し， $\alpha$ 相領域にて熱処理を施 すことにより，酸素を均一化したチタン材における強度と伸 びの関係を確認する ${ }^{13,14)}$ ０.0\%酸素添加チタン材では，その 破断伸びは $40 \%$ 程度であったのに対して， $0.2 \%$ の酸素の添加 により $25 \%$ 程度まで急激に低下する，その後, 酸素の添加に 伴って，破断伸びは徐々に低下するが，0.60 mass\%酸素添加 
チタン材では15\%を超える優れた破断伸びを示している。こ れを超えると破断伸びは再び急激に低下し， 0.75 mass\%酸素 添加チタン材では，その破断伸びは $0 \%$ となる.一方で, 0.75 mass\%を大きく超える 0.94 mass\%の酸素を添加したチタン 材において，UTS $1094 \mathrm{MPa}$ を達成しながら， 5 \%を超える 破断伸びを維持できることを報告した ${ }^{15)}$. しかしながら，酸 素添加に伴うチタン材の脆化挙動, および酸素過剩添加チ夕 ン材における延性回復機構については未だ明らかにされてい ない.

そこで, 本研究では, 酸素過剩添加チタン材を対象に, 固 溶酸素原子の分布状態に着目し, 熱処理過程での相変態挙動 と粒界近傍での酸素濃度の関係を詳細に解析することで延性 向上機構の解明を目指す.

\section{2. 実 験 方 法}

出発原料として, 純度 $99.9 \%$, メジアン径 $27.8 \mu \mathrm{m}$ の純 $\mathrm{Ti}$ 粉末 (TC-450：トーホーテック(株)製) および純度 $99.9 \%$, メジ アン径 $3.6 \mu \mathrm{m}$ のルチル型 $\mathrm{TiO}_{2}$ 粒子((株)高純度化学研究所製) を準備した．先ず，混合粉末全体における酸素含有量が 0.94 mass \%となるように両粉末原料を配合した後, ロッキングミ ル混合機 $(\mathrm{RM}-01$ ， (株)セイワ技研製）を用いて大気中にて 3.6 $\mathrm{ks}$ の混合処理を施し, $\mathrm{TiO}_{2}$ 粒子が均一に分散する $\mathrm{Ti}^{-}-\mathrm{TiO}_{2}$ 混 合粉末を作製した. 各混合粉末は Fig. 1 に示すフローチャー トに基づき, 放電プラズマ焼結装置 (Spark Plasma Sintering, SPS, SPS-1030S, SPS シンテックス(株)製)を用いて, 真空雲 囲気 $(6 \mathrm{~Pa})$ のもとで焼結温度 $1100^{\circ} \mathrm{C}$ と, 保持時間 $3.6 \mathrm{ks}$ に て固相焼結を行った. その際, 混合粉末は直径 $42 \mathrm{~mm}$ のカー ボン製コンテナに充填し, 上記の温度で加熱した状態で上下 方向からカーボン製パンチを介して $30 \mathrm{MPa}$ の加圧力を混合 粉末に対して付与した. 続いて, 真空電気炉 (FT-1200R-120, フルテック(株)製)を用いて組成の均質化のための真空熱処理を 施した. チャンバー内を $20 \mathrm{~Pa}$ 程度まで真空排気し, $20^{\circ} \mathrm{C} /$

\section{Elemental mixture of $\mathrm{Ti}_{-} \mathrm{TiO}_{2}$ powder}

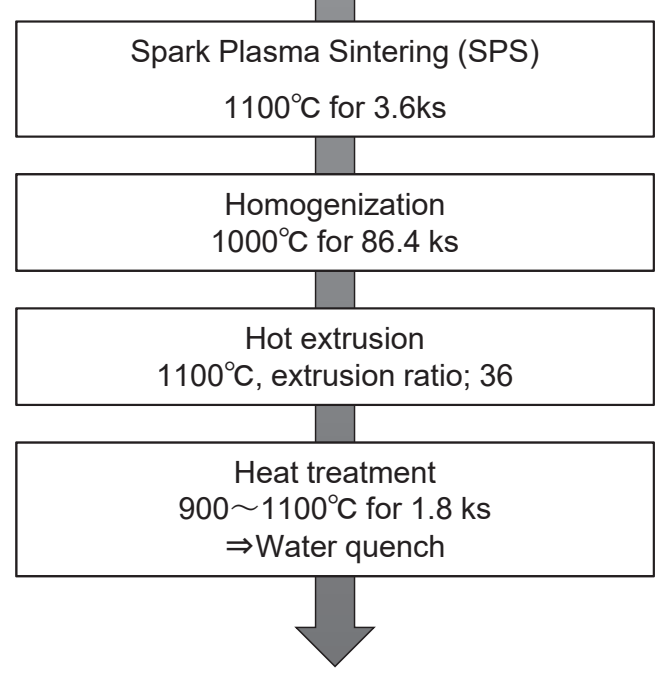

\section{Quenched Ti(O) materials}

Fig. 1 Flowchart of specimen preparation of quenched $\mathrm{Ti}^{-}-0.94$ mass $\% 0$ materials $(\mathrm{Ti}(\mathrm{O})-X X X \mathrm{Q})$ by powder metallurgy route. $\min$ の昇温速度で室温から $1000^{\circ} \mathrm{C}$ まで加熱して $86.4 \mathrm{ks}$ 保持し た。 その後, 得られた各焼結体の完全緻密化を図るべく, ア ルゴンガス䨌囲気中で, $1100^{\circ} \mathrm{C} に て ~ 300 \mathrm{~s}$ の予備加熱を行い, 直ちに熱間押出加工を施して棒状チタン素材を作製した。 そ の際, 押出比は36 $(\Phi 43 \mathrm{~mm} \rightarrow \Phi 7 \mathrm{~mm})$, 押出ラム速度は 3.0 $\mathrm{mm} / \mathrm{s}$ とした. 得られた押出材に対してアルゴンガス雲囲気 中で $900^{\circ} \mathrm{C}$ から $1100^{\circ} \mathrm{C}$ の各温度にて $1.8 \mathrm{ks}$ の予備加熱を行い, 直ちに水焼入れを施して急冷した。 この予備加熱温度を急冷 処理温度とし, 各急冷処理温度 $\left(\mathrm{T}=X X X^{\circ} \mathrm{C}\right)$ から急冷した試料 を $\mathrm{Ti}(\mathrm{O})-X X X \mathrm{Q}$ とした。

押出材の力学特性の評価に関しては, 各素材から機械加工 により引張試験片 (平行部の直径 $4 \mathrm{~mm}$, 長さ $15 \mathrm{~mm}$ ) 2 本 採取し, 万能引張試験機 (Autograph AG-X $50 \mathrm{kN}$, (株)島津製作 所製)を用いて常温にて歪み速度 $5 \times 10^{-4} / \mathrm{s}$ のもとで引張試験 を行い, 引張強さ， $0.2 \%$ 耐力, 破断伸びを測定した. また, 組織観察については, 走査型電子顕微鏡 (Scanning Electron Microscope, SEM, JSM-6500F, 日本電子(株製)とそれに併 設する電子線後方散乱回析装置 (Electron Backscatter Diffraction, EBSD/Orientation Imaging Microscopy, OIM, DigiView IV Detector：(株)TSLソリューションズ製)システムを用いた 組織構造・結晶方位解析, および電子プローブマイクロアナ ライザ(Electron Probe Micro Analyzer, EPMA, JXA-8530F, 日 本電子(株製)による元素分析を行った。

\section{3. 実験結果および考察}

まず, 酸素固溶チタン材において, 急冷処理温度と力学特 性の関係を調査すべく, 本研究で作製した Ti-0.94 mass \% O 押出材に対して $900 \sim 1100^{\circ} \mathrm{C}$ の各温度から急冷熱処理を施し, それぞれに対して常温にて引張試験を行った。その結果を Fig. 2 に示す. 急冷処理前の押出まま材 (As extruded)の力学 特性として, UTS は $1079 \mathrm{MPa}$, YS は $1032 \mathrm{MPa}$, 破断伸び は6.0\%であった. 次に, 急冷熱処理を施したチタン材の特性 について, Ti(O)-900Qの破断伸びは $1.2 \%$ まで低下したのに対 して, Ti (O)-950Q, 1000Qの破断伸びは押出まま材に比べて高 い值を有しており，それぞれ12.5，19.1\%まで増加した。 そして， 急冷処理温度を $1050^{\circ} \mathrm{C}$ およ゙ $1100^{\circ} \mathrm{C}$ とした $\mathrm{Ti}(\mathrm{O})-1050 \mathrm{Q}$, $1100 \mathrm{Q}$ では再び破断伸びは，それぞれ $0.1 ， 0.5 \%$ に低下し，引 張試験において弾性域で破断した。一方で, その強度につい ては, $900^{\circ} \mathrm{C}$ から $1100^{\circ} \mathrm{C}$ の急冷処理温度を採用した各試料 Ti(O)-900〜1100Q にて，UTS はそれぞれ1006，993，988, 814, $919 \mathrm{MPa}$ YSはそれぞれ966, 799, 791，789，892 MPa であった．著しい延性向上を示した Ti (O)-950Q, 1000Qでは， その引張曲線はラウンドハウス型に移行してYS は低下した ものの, UTS は Ti $(\mathrm{O})-900 \mathrm{Q}$ と同程度の值となった。 また, $\mathrm{Ti}(\mathrm{O})-900 \mathrm{Q}, 950 \mathrm{Q}, 1000 \mathrm{Q}$ の引張強さは, 押出まま材に比べ て約 $170 \mathrm{MPa}$ 低下していたが，これは主として熱処理による $\alpha-\mathrm{Ti}$ 結晶粒の粗大化によるものと考えられる ${ }^{11,12)}$.

次に，急冷熱処理温度と破断伸びの関係を明らかにすべく， 各温度における Ti-0.94 mass\% O の相構成を示した $\mathrm{Ti}-\mathrm{O}$ 系 平衡状態図 ${ }^{22}$ を Fig. 3(a) に示す. 上記の引張試験結果と対比 すると, 延性が顕著に低下した急冷処理温度 $900^{\circ} \mathrm{C}$ では $\alpha$ 単 


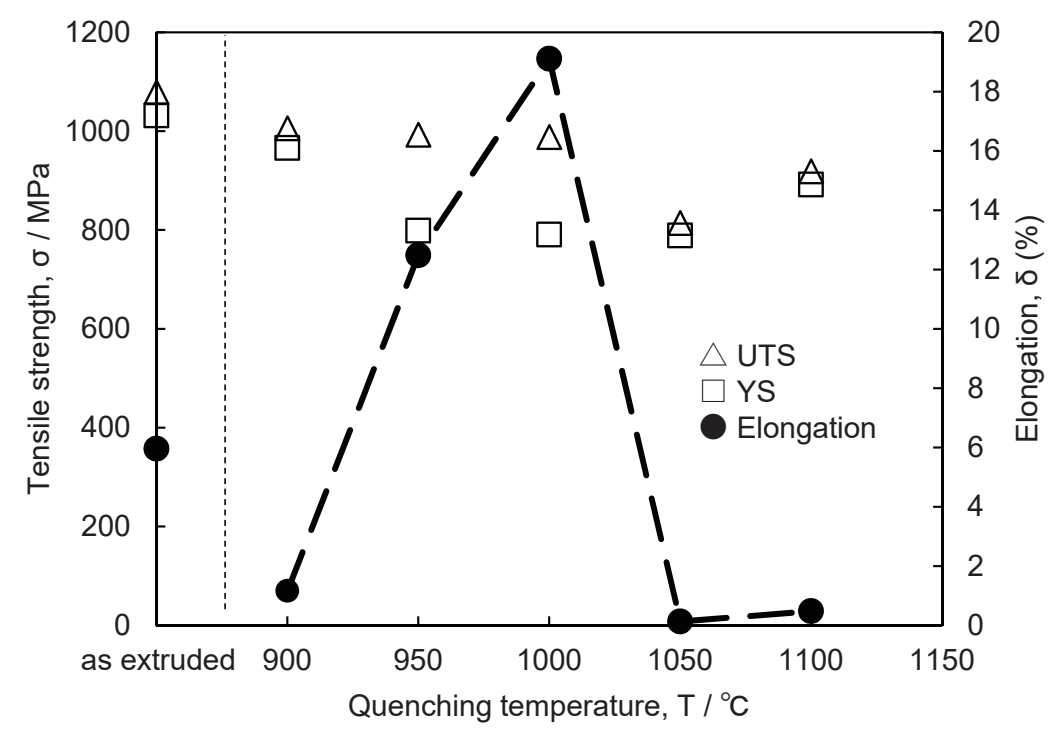

Fig. 2 Dependence of tensile properties of $\mathrm{Ti}(\mathrm{O})-\mathrm{XXXQ}$ materials on quenching temperature.
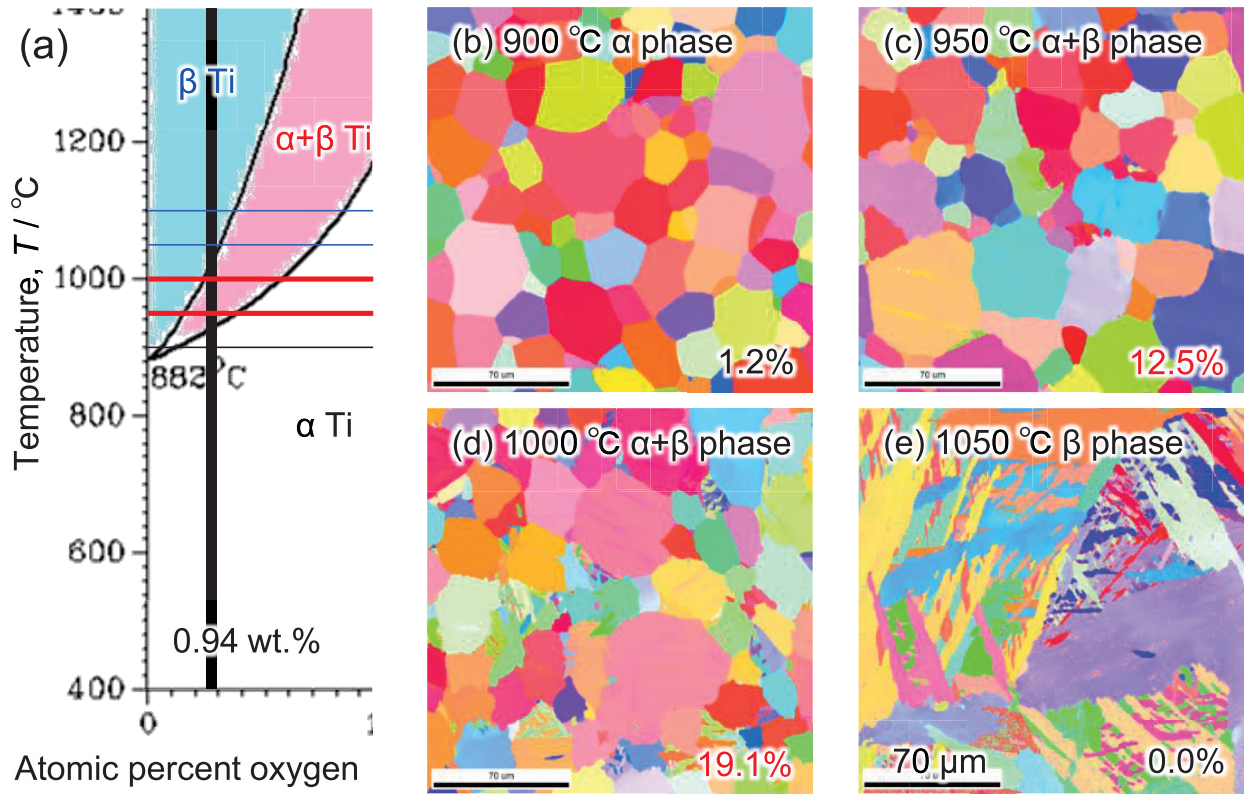

Fig. 3 Ti-O binary phase diagram (a) and IPF maps of Ti(O)-900Q (b), Ti(O)-950Q (c), Ti(O)-1000Q (d) and Ti(O)-1050Q (e).

相，同じく $1050^{\circ} \mathrm{C}, 1100^{\circ} \mathrm{C}$ では $\beta$ 単相であり，一方，延性が

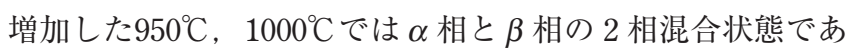
ることがわかる，そこで，それぞれの相状態から急冷処理を 施した試料の組織構造を IPF map により調査した，その結果 を Fig. 3(b)〜 (e)に示す. $\alpha$ 単相温度域から急冷処理した $\mathrm{Ti}(\mathrm{O})-900 \mathrm{Q}$ は等軸粒の $\alpha$ 相から構成されて抢り, $\beta$ 単相域

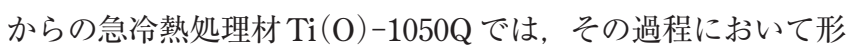
成されたマルテンサイト相 $\left(\alpha^{\prime}\right.$ 相)を含む異形状な結晶粒に より構成されていることを確認した。他方， $\alpha$ 相と $\beta$ 相の 2 相混合状態から急冷処理した試料 (c) Ti (O) - $950 \mathrm{Q}$ と (d) $\mathrm{Ti}(\mathrm{O})-1000 \mathrm{Q}$ では, 主として $\alpha-\mathrm{Ti}$ 等軸粒により構成されて いるものの, 一部の結晶粒界に $10 \mu \mathrm{m}$ 程度の $\alpha$ 相が生成す る他, 粒内に执いては方位の不整合が筋状に形成されている ことを確認した。 また, Ti (O)-900Q, 950Q, 1000Q の平均 結晶粒径はそれぞれ $31.9,36.2,30.1 \mu \mathrm{m}$ であり, 顕著な差異 が見られなかった。ここで，粒界に形成された $\alpha^{\prime}$ 相抢よび粒
内に形成された方位の不整合に着目して, 本急冷熱処理材に おける組織形成機構を考える. 前出の平衡状態図によると, 酸素固溶チタン材の $\alpha$ 相と $\beta$ 相の 2 相混合状態においては, $\alpha$ 相に扔ける酸素の固溶量は $\beta$ 相の酸素固溶料と比較して 2 倍以上高くなることから，これを急冷処理した試料に打いて も， $\alpha$ 相由来と $\beta$ 相由来のそれぞれの $\alpha-\mathrm{Ti}$ 結晶粒では酸素固 溶量に差が生じると考えられる。 そこで, 酸素の分布状態を SEM-EPMAにより調查した。 その結果を Fig. 4 に示す. 酸 素はチタン母相に濃化して㧍り, 粒界に形成された $\alpha^{\prime}$ 相抢よ び粒内に形成された筋状の方位の不整合領域では酸素含有量 の低下が確認された。先述のように, Ti 中の酸素原子は $\alpha$ 相 と $\beta$ 相の 2 相混合状態に扔いて $\alpha$ 相に濃化し, $\beta$ 相中ではそ の濃度は低下する。したがって, これらの酸素含有量の低下 した 2 領域は高温域において形成される $\beta$ 相に由来した組織 であり，また $\operatorname{Ti} の ~ \alpha$ 相母相は $\alpha$ 相由来の組織といえる.

そこで, 急冷過程を経てこのような組織が形成されるメカ 
ニズムについて, Fig. 5 に示す模式図に基づいて考察する. まず， $\alpha$-Ti 結晶粒内に筋状に形成された方位の不整合につい て, $\alpha$ 相と $\beta$ 相の 2 相混合状態では, Burgers の方位関係 ${ }^{23)}$ に従って扁平状の $\beta$ 相が $\alpha$ 相内に形成されており ${ }^{24,25)}$, 状態 図によると $\beta$ 相の体積率は約 $90 \%$ となっていると考えられる. この状態で急冷熱処理すると, $\beta$ 相への相変態時と同様に Burgers の方位関係と周囲の $\alpha$ 相の影響により $\alpha$ 相粒内に形 成された $\beta$ 相は, $\alpha$ 相と $\beta$ 相の粒界を起点として，接してい る $\alpha$ 相と同じ方向に相変態が進行すると考えられる. その際, $\beta$ 相は bcc 構造を有するために hcp 構造の $\alpha$ 相に相変態する 際に体積は減少する。 その結果, $\beta$ 相から $\alpha$ 相への相変態に おける最終段階では，この体積減少に基づいて生じる歪みが 蓄積して同一方向への変態が制限され，粒内において方位の 不整合が形成されたと考えられる．次に，結晶粒界に形成さ れた $\alpha^{\prime}$ 相について, チタンにおける $\alpha$ 相は, $\beta$ 相からの急 冷過程において形成されることが報告されており ${ }^{26-28)}$, 本研 究で取り扱う Ti-0.94 mass\% O においても Fig. 3 に示したよ うに $\beta$ 単相から急冷熱処理を施した Ti $(\mathrm{O})-1050,1100 \mathrm{Q}$ では, 試料全体に $\alpha$ 相の形成が確認されている。 また Ti $(\mathrm{O})-950 \mathrm{Q}$, 1000Q において, 粒界に形成された $\beta$ 相が $\alpha$ 相に相変態する

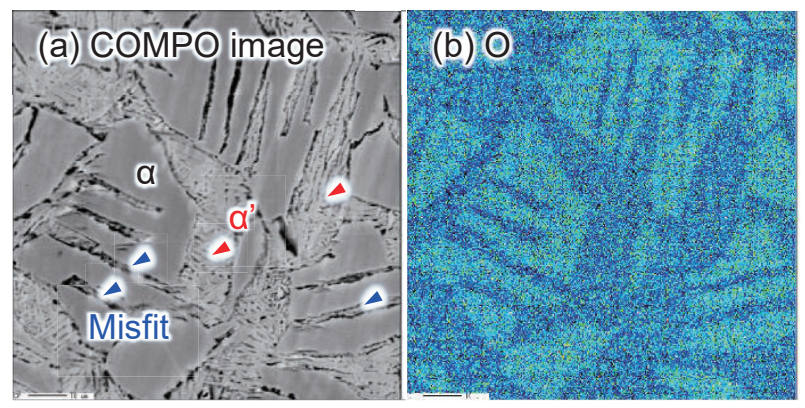

Fig. 4 Backscattered electron image (a) and EPMA O-mapping analysis results $(\mathrm{b})$ of $\mathrm{Ti}(\mathrm{O})-1000 \mathrm{Q}$.
際，粒内に形成された $\beta$ 相とは異なり，周囲に接する複数の 結晶粒の方位の影響を受けるため, 異なる方位を有する複数 の核を生成し， $\alpha$ 相を形成したと考えられる.

ここで, $1000^{\circ} \mathrm{C}$ から急冷熱処理によって形成した上記の 組織構造に起因する高延性発現機構について考察する。まず, 急冷処理材 $\mathrm{Ti}(\mathrm{O})-1000 \mathrm{Q}$ における塑性変形機構を明らかにす ベく, 引張試験の前後での試料の破断部近傍における KAM 解析結果を IPF map とともに Fig. 6 に示す. KAM map では, 隣接する 2 点間の結晶方位差を表しており, これは素地に導 入された歪みとの間に強い相関を有することから，ここでは $\mathrm{KAM}$ 值を用いて結晶粒レベルでの局所的な塑性変形挙動を
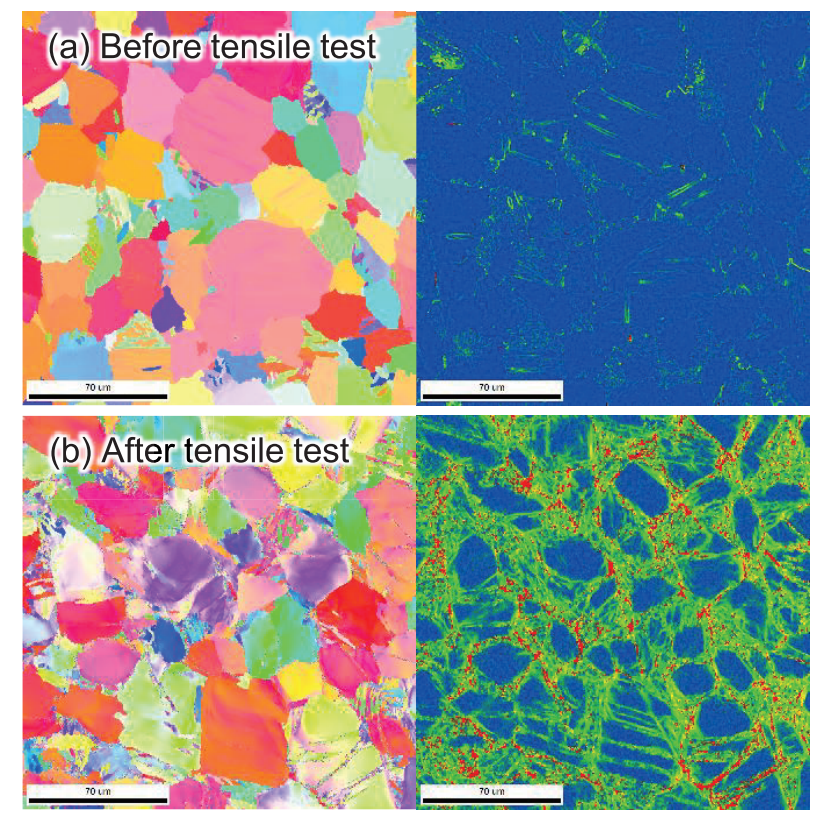

Fig. 6 IPF maps and KAM maps of $\mathrm{Ti}(\mathrm{O})-1000 \mathrm{Q}$ before (a) and after (b) tensile test.
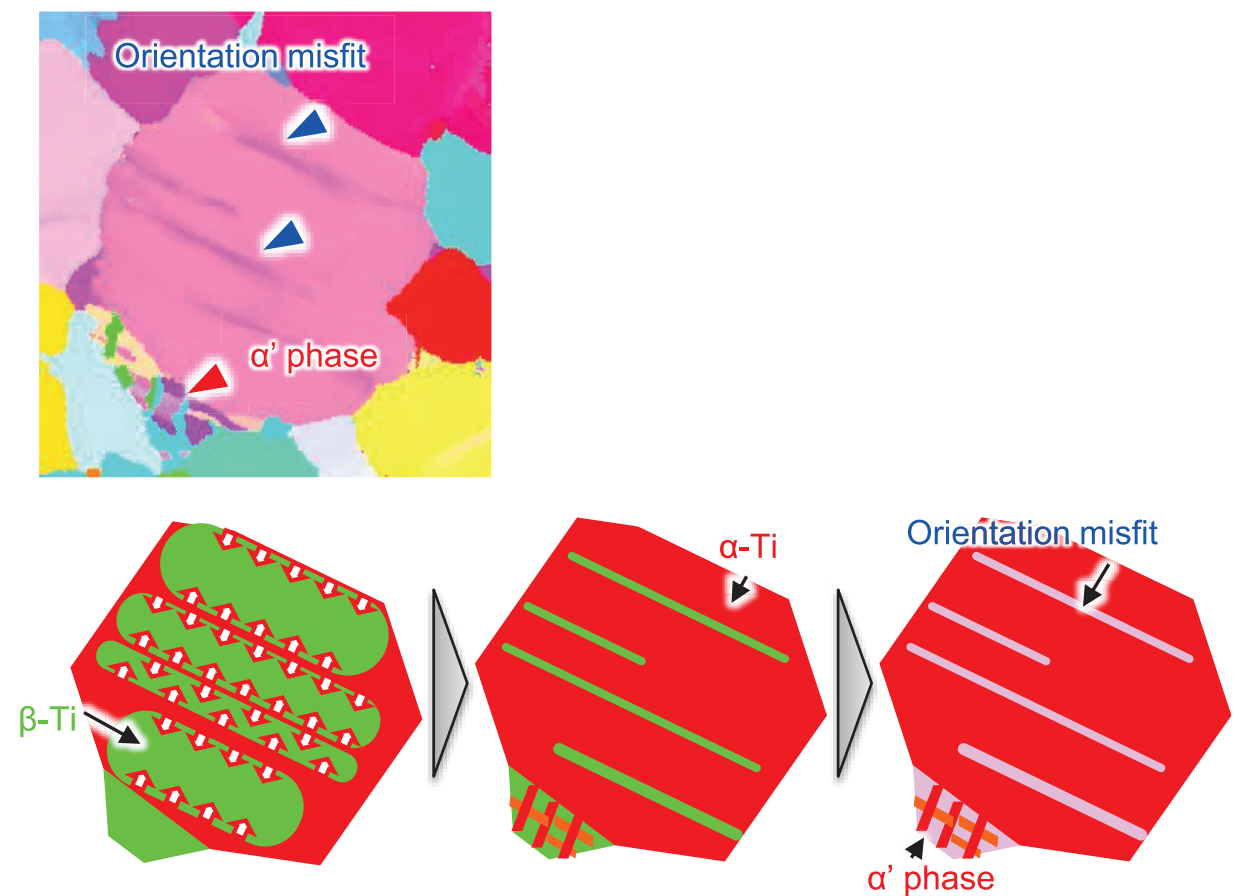

Fig. 5 Schematic illustrations of formation of $\alpha$ phase on grain boundary and orientation misfit area in $\alpha$ grain. 
解析する（a）に示すように引張試験前は粒界がわずかに緑色 で表される程度であり，残留歪みも限定的であるが，（b）の 引張試験後では結晶粒界の他, 一部の粒内においても明暸に 赤色や緑色で示されているように多くの筋状の歪みが導入さ れていることがわかる。ここで確認された粒界における歪み は粒界すべり，粒内の筋状領域における歪は転位運動による もの ${ }^{29-31)}$ と考えられる. 前出の Fig. 4 に示した SEM-EPMA 分析結果で述べたように急冷処理材においては，結晶粒界お よび一部の結晶粒内では筋状に形成された方位の不整合領域 において酸素濃度が低下していた。ゆえに， $\alpha$ 相と $\beta$ 相の 2 相混合状態から急冷熱処理を施した酸素固溶チタン材では, 酸素濃度が低下した結晶粒界で活性化したすべりと, 結晶粒 内での方位の不整合領域における転位運動が塑性変形を担う 結果，本材料の破断伸び值が増大したと考えられる.

次に，微細組織構造が伸び值に及ぼす影響を調査すべく， $\mathrm{Ti}(\mathrm{O})-1000 \mathrm{Q}$ に対して真空中にて $400^{\circ} \mathrm{C}$ および $600^{\circ} \mathrm{C} に て 24$ 時 間の熱処理を施し, 得られた組織構造と引張特性の関係を調 査した. $\mathrm{Ti}(\mathrm{O})-1000 \mathrm{Q}$ (As quenched) とこれに対して上記の 温度で熱処理を施した各試料の IPF map を Fig. $7(\mathrm{a}) \sim(\mathrm{c})$ に, また $\mathrm{Ti}(\mathrm{O})-1000 \mathrm{Q}$ とこれに $600^{\circ} \mathrm{C} て ゙$ 熱処理を施した試料につ いて酸素の分布状態を EPMA 分析により調查した結果を反射 電子像とともに Fig. 8 に示す。なお， (a)〜 (c) においては各 試料の破断伸び值を併記した。 まず，組織解析結果に関して， いずれの組織の概観に大きな差はなく，主として等軸粒の $\alpha$ 相粒により構成されており，各温度で焼鈍処理を施した試料 の粒径は急冷まま材で $30.1 \mu \mathrm{m}$ であったのに対し，焼鈍温度 $400^{\circ} \mathrm{C}$ では $25.2 \mu \mathrm{m}$, 焼鈍温度 $600^{\circ} \mathrm{C}$ では $25.0 \mu \mathrm{m}$ であった. また，結晶粒界に形成された $\alpha$ 相はいずれの熱処理において も残存しているものの，粒内に形成された方位の不整合領域 については， $400^{\circ} \mathrm{C}$ 以上での熱処理により完全に消失している ことを確認した．また，各試料の破断伸び值は $\mathrm{Ti}(\mathrm{O})-1000 \mathrm{Q}$ にて $19.1 \% ， 400^{\circ} \mathrm{C} ， 600^{\circ} \mathrm{C}$ で熱処理を施した試料にて $15.5 \%$,
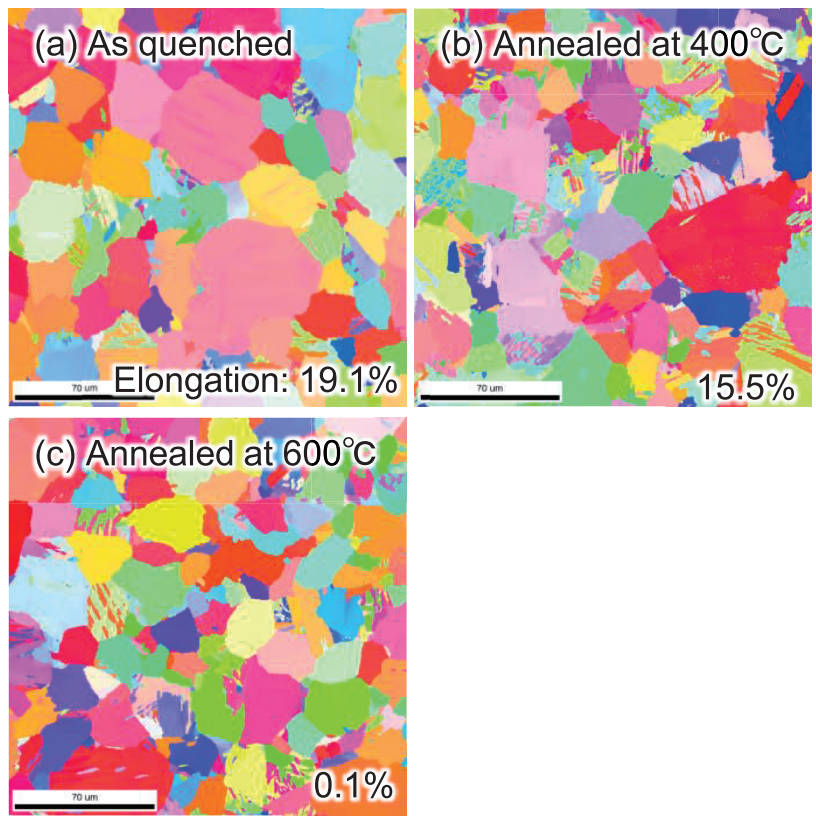

Fig. 7 IPF maps of $\mathrm{Ti}(\mathrm{O})-1000 \mathrm{Q}$ annealed at each temperature; (a) as quenched and annealed at (b) $400^{\circ} \mathrm{C}$ and (c) $600^{\circ} \mathrm{C}$.

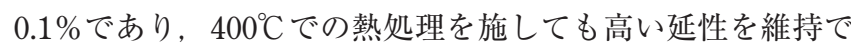
きているものの, $600^{\circ} \mathrm{C}$ での熱処理材の伸び值は著しく低下し た。このことから熱処理後の組織構造と破断伸び值の間には 明瞭な相関はないと考えられる。そこで，熱処理により伸び 值が低下した要因について, Fig.5での考察結果に基づき, 上 記の熱処理が $\alpha-\mathrm{Ti}$ 素地中の固溶酸素の分布状態への影響の 点から考察を行う. Fig. 8(a)に示す急冷熱処理材において, 結晶粒内および粒界部での固溶酸素原子の濃淡は明確に区別 されているが，(b)の $600^{\circ} \mathrm{C}$ 熱処理材ではその境界は不明瞭と なり，熱処理前に粒内に濃化していた固溶酸素は熱処理過程 において拡散したと考えられる。ここで，各熱処理温度にお けるチタン中での酸素の拡散速度 ${ }^{32)}$ を比較すると, $600^{\circ} \mathrm{C}$ では $6.7 \times 10^{-5} \mu \mathrm{m}^{2} / \mathrm{s}, \quad 400^{\circ} \mathrm{C}$ では, $2.1 \times 10^{-8} \mu \mathrm{m}^{2} / \mathrm{s}$ であり, 熱処理 温度が $200^{\circ} \mathrm{C}$ 増加することで拡散速度は著しく増大しており, このことから $600^{\circ} \mathrm{C}$ で熱処理を施した試料では, 結晶粒内に濃 化した固溶酸素が熱処理過程で酸素濃度が相対的に小さい粒 界や粒内の筋状領域に拡散したと考えられる. その結果, 酸 素濃度が低下したことで塑性変形を担っていた 2 領域に酸素 が流入し，塑性変形能が低下したことで脆化したものと考え られる。一方で, 室温 $\left(27^{\circ} \mathrm{C}\right)$ では, その拡散係数は $2.1 \times 10^{-27}$ $\mu \mathrm{m}^{2} / \mathrm{s}$ と極めて小さいことから室温での固溶酸素原子の拡散 は無視できると考えられ, 結晶粒界への拡散現象を伴わない 結果，高い破断伸び值を維持できたといえる.

以上の結果より, 酸素過剩添加チタン材では, $\alpha$ 相と $\beta$ 相 の混合温度域において, 酸素は $\alpha$ 相に濃化しており, $\alpha$ 相粒 界および粒内に形成された微細な扁平 $\beta$ 相粒における酸素濃 度は低下した。この状態から急冷処理を施すことにより, 粒 内および粒界に形成された $\beta$ 相粒は筋状の方位の不整合域を 形成するとともに， $\alpha$ 相を生成した。また，急冷処理時には 拡散速度の大きい高温領域における酸素の拡散は制限され， $\beta$ 相由来の 2 領域において酸素が微細に偏析した状態を維持し た組織が形成されることを示した。このような 2 相混合状態
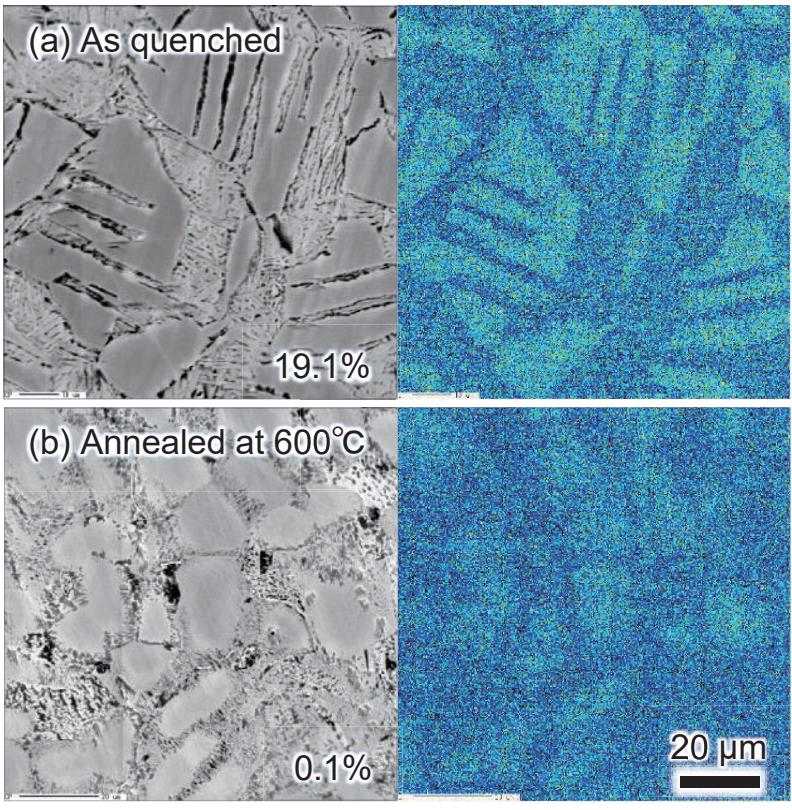

Fig. 8 Backscattered electron image and EPMA O-mapping analyze results of as quenched $\mathrm{Ti}(\mathrm{O})-1000 \mathrm{Q}$ (a) and that annealed at $600^{\circ} \mathrm{C}(\mathrm{b})$. 
からの急冷処理により作製したチタン材において, 酸素濃度 の低下した上記の 2 領域が転位運動および粒界すべりにより 塑性変形を担うため, 優れた延性を発現することが明らかに なった。

\section{4. 結言}

本研究では, 酸素の過剩添加 $(0.94$ mass\%)によって伸び值 が低下したチタン材を対象に，固溶酸素の粒界および粒内で の分布状態に着目し, 熱処理過程での相変態挙動と粒界近傍 での酸素濃度の関係を詳細に解析することで延性向上機構の 解明を試みた。 その中で, $\alpha$ 相と $\beta$ 相の混合温度域から急冷 処理を施すことにより最大応力 $988 \mathrm{MPa}$ を維持しながら, そ の破断伸びは最大で $19.1 \%$ まで回復することを確認した．本 急冷材は，等軸 $\alpha-T i$ 結晶粒と粒界における $\alpha$ 相，粒内にお ける筋状の方位の不整合相から構成されており, 酸素は等軸 粒の $\alpha$ 相に濃化し， $\alpha$ 相，方位の不整合領域においては，そ の酸素濃度は低下していることを確認した． $\alpha$ 相と $\beta$ 相が混 在する高温域では, 酸素は $\alpha$ 相に濃化し, $\beta$ 相の酸素濃度は 低下することから酸素濃度の低下が確認された 2 領域は $\beta$ 相 に由来する領域であり, 急冷処理により酸素分布状態が保持 されることで酸素濃度が低下した. EBSD 解析の結果, この ような酸素濃度の低下領域には強い歪みが導入されており, これらの領域が塑性変形を担うことにより高い破断伸び值を 示したものと考えられる.

本研究の一部は, 科学技術振興機構(JST) 産学共創基礎基 盤研究プログラム・革新的構造用金属材料創製を目指したへ テロ構造制御に基づく新指導原理の構築, および日本学術振 興会 (JSPS) 科学研究費補助金事業・基盤 A(16H02408)による ものである.

文献

1) Japan Society for Technology of Plasticity: Fundamentals of Titanium and Its Working, (Corona Publishing Co., Ltd., Tokyo, 2008).

2) M. Niinomi: Basic Materials Science, Manufacturing and Newly
Advanced Technologies of Titanium and Its Alloys, (CMC Publishing Co., Ltd., Tokyo, 2009).

3) K. Wang: Mater. Sci. Eng. A 213(1996) 134-137.

4) M. Niinomi, M. Nakai and J. Hieda: Acta Biomater. 8(2012) 38883903.

5) M. T. Mohammed: Karbala International Journal of Modern Science 3(2017) 224-230.

6) I. Ohkata: J. Jpn. Soc. Mech. Eng. 107 (2004) 532-535.

7) S. Georgiadis, A. J. Gunnion, R. S. Thomson and B. K. Cartwright: Composite Structures 86(2008) 258-268.

8) M. Balazic, J. Kopac, M. J. Jackson and W. Ahmed: Int. J. Nano Biomater. 1 (2007) 3-34.

9) S. Li, B. Sun, H. Imai, T. Mimoto and K. Kondoh: Composites Part A 48(2013) 57-66.

10) X. Zhang, F. Song, Z. Wei, W. Yang and Z. Dai: Mater. Sci. Eng. A 705(2017) 153-159.

11) M. J. Bermingham, S. D. McDonald, M. S. Dargusch and D. H. StJohn: Scr. Mater. 58(2008) 1050-1053.

12) S. Mereddy, M. J. Bermingham, D. H. StJohn and M. S. Dargusch: J. Alloy. Compd. 695(2017) 2097-2103.

13) R. I. Jaffee, H. R. Ogden and D. J. Maykuth: Transactions of A.I.M.E. 181 (1951) 1261.

14) W. L. Finlay and J. A. Snyder: Transactions of A.I.M.E. 188(1951) 277.

15) S. Kariya, M. Fukuo, J. Umeda and K. Kondoh: J. Jpn. Soc. Powder Powder Metallurgy 65(2018) 407-413.

16) Y. Yamabe, J. Umeda, H. Imai and K. Kondoh: J. Jpn. Soc. Powder Powder Metallurgy 64(2017) 275-280.

17) H. Conrad: Prog. Mater. Sci. 26 (1981) 123-403.

18) S. Zhu, T. Luo, T. Zhang, Y. Li and Y. Yang: Mater. Sci. Eng. A 689(2017) 203-211.

19) B. Sun, S. Li, H. Imai, T. Mimoto, J. Umeda and K. Kondoh: Mater. Sci. Eng. A 563(2013) 95-100.

20) D. Kang, K. Lee, E. Kwon, T. Tsuchiyama and S. Takaki: Mater. Sci. Eng. A 632(2015) 120-126.

21) Y. Murayama, M. Mikami, S. Ishiyama and S. Hanada: J. Japan Inst. Metals 57 (1993) 628-636.

22) J. L. Murray: Phase Diagram of Binary Titanium Alloys, (ASM International, Ohio, 1987).

23) W. G. Burgers: Physica 1(1939) 561-586.

24) K. Okazaki and H. Conrad: Acta Metall. 21 (1973) 1117-1129.

25) M. L. Wasz, F. R. Brotzen, R. B. McLellan and A. J. Griffin Jr: Int. Mater. Rev. 41(1996) 1.

26) R. I. Jaffee: Progress in Metal Physics 7(1958) 65-163.

27) S. A. Souza, C. R. M. Afonso, P. L. Ferrandini and R. Caram: Mater. Sci. Eng. C 29(2009) 1023-1028.

28) A. Foul, C. Aranas, B. Guo and J. J. Jonas: Mater. Sci. Eng. A 722(2018) 156-159.

29) T. Sakai, A. Belyakov, R. Kaibyschev, H. Miura and J. J. Jonas: Prog. Mater. Sci. 60 (2014) 130-207.

30) A. Sarkar, M. K. Dash, A. Nagesha, A. Dasgupta, R. Sandhya and M. Okazaki: Mater. Sci. Eng. A 723 (2018) 229-237.

31) P. Chen, S. C. Mao, Y. Liu, F. Wang, Y. F. Zhang, Z. Zhang and X. D. Han: Mater. Sci. Eng. A 580 (2013) 114-124

32) D. David, E. Garcia, X. Lucas and G. Beranger: J. Less-Common Met. 65(1979) 51-69. 